Article

\title{
Hypothalamic Expression of Neuropeptide Y (NPY) and Pro-OpioMelanoCortin (POMC) in Adult Male Mice Is Affected by Chronic Exposure to Endocrine Disruptors
}

\author{
Marilena Marraudino ${ }^{1,2,+} \mathbb{D}$, Elisabetta Bo ${ }^{1,2,+}$, Elisabetta Carlini ${ }^{1,2}$, Alice Farinetti ${ }^{1,2}$, Giovanna Ponti ${ }^{2} \mathbb{D}$, \\ Isabella Zanella ${ }^{3}{ }^{(}$, Diego Di Lorenzo ${ }^{4}$, Gian Carlo Panzica ${ }^{1,2}{ }^{(D)}$ and Stefano Gotti ${ }^{1,2, *(\mathbb{D})}$ \\ 1 Laboratory of Neuroendocrinology, Department of Neuroscience, University of Torino, 10126 Torino, Italy; \\ marilena.marraudino@unito.it (M.M.); bo.elisabetta@gmail.com (E.B.); carlinielisabetta@hotmail.it (E.C.); \\ alice.farinetti@unito.it (A.F.); giancarlo.panzica@unito.it (G.C.P.) \\ 2 Neuroscience Institute Cavalieri-Ottolenghi (NICO), 10043 Orbassano, Italy; gponti2@gmail.com \\ 3 Department of Molecular and Translational Medicine, University of Brescia, 25121 Brescia, Italy; \\ isabella.zanella@unibs.it \\ 4 Clinical Chemistry Laboratory, Diagnostic Department, ASST Spedali Civili di Brescia, 25123 Brescia, Italy; \\ diego.dilorenzo@asst-spedalicivili.it \\ * Correspondence: stefano.gotti@unito.it; Tel.: +39-011-6706610; Fax: +39-011-2367054 \\ + Equally contributed and should be considered as joint first authors.
}

Citation: Marraudino, M.; Bo, E.; Carlini, E.; Farinetti, A.; Ponti, G.; Zanella, I.; Di Lorenzo, D.; Panzica, G.C.; Gotti, S. Hypothalamic Expression of Neuropeptide Y (NPY) and Pro-OpioMelanoCortin (POMC) in Adult Male Mice Is Affected by Chronic Exposure to Endocrine Disruptors. Metabolites 2021, 11, 368. https://doi.org/10.3390/

metabo11060368

Academic Editor: Amedeo Lonardo

Received: 24 March 2021

Accepted: 6 June 2021

Published: 9 June 2021

Publisher's Note: MDPI stays neutral with regard to jurisdictional claims in published maps and institutional affiliations.

Copyright: (c) 2021 by the authors. Licensee MDPI, Basel, Switzerland. This article is an open access article distributed under the terms and conditions of the Creative Commons Attribution (CC BY) license (https:/ / creativecommons.org/licenses/by/ $4.0 /)$.
Abstract: In the arcuate nucleus, neuropeptide Y (NPY) neurons, increase food intake and decrease energy expenditure, and control the activity of pro-opiomelanocortin (POMC) neurons, that decrease food intake and increase energy expenditure. Both systems project to other hypothalamic nuclei such as the paraventricular and dorsomedial hypothalamic nuclei. Endocrine disrupting chemicals (EDCs) are environmental contaminants that alter the endocrine system causing adverse health effects in an intact organism or its progeny. We investigated the effects of long-term exposure to some EDCs on the hypothalamic NPY and POMC systems of adult male mice that had been previously demonstrated to be a target of some of these EDCs after short-term exposure. Animals were chronically fed for four months with a phytoestrogen-free diet containing two different concentrations of bisphenol A, diethylstilbestrol, tributyltin, or $\mathrm{E}_{2}$. At the end, brains were processed for NPY and POMC immunohistochemistry and quantitatively analyzed. In the arcuate and dorsomedial nuclei, both NPY and POMC immunoreactivity showed a statistically significant decrease. In the paraventricular nucleus, only the NPY system was affected, while the POMC system was not affected. Finally, in the VMH the NPY system was affected whereas no POMC immunoreactive material was observed. These results indicate that adult exposure to different EDCs may alter the hypothalamic circuits that control food intake and energy metabolism.

Keywords: endocrine disrupting chemicals; bisphenol A; diethylstilbestrol; tributyltin; neuropeptide Y; pro-opiomelanocortin

\section{Introduction}

Two neurochemically distinct sets of hypothalamic neurons controlling food intake are located in the arcuate nucleus (ARC). One group expresses neuropeptide Y (NPY) and agouti-related protein (AgRP). The NPY release by these neurons results in increased food intake and decreased energy expenditure. The other group expresses cocaine- and amphetamine-regulated transcript (CART) and pro-opiomelanocortin POMC, which is processed to melanocortin peptides, such as $\alpha$-melanocyte-stimulating hormone ( $\alpha$-MSH). The activation of these neurons decreases food intake and increases energy expenditure [1] with an opposite effect of the NPY / AgRP system. Interactions between these two populations allow the NPY neurons to control the activity of the POMC cells. NPY/AgRP and POMC/CART neuronal projections reach hypothalamic nuclei such as the paraventricular 
nucleus (PVN), dorsomedial hypothalamic nucleus (DMH), and perifornical area [2]. These secondary centers process information regarding energy homeostasis.

Many factors can influence the activity of this system (for example the secretion of leptin by adipocytes), but estrogenic signaling may intersect at several levels with the hypothalamic circuits controlling food intake [3]. In fact, estradiol is involved in the regulation of metabolism through the modulation of food intake, body weight, glucose/insulin balance, body fat distribution, lipogenesis, lipolysis, and energy consumption [4]. The estradiol regulates neuroendocrine circuits controlling the metabolism [5] by acting on the POMC neurons through the estrogen receptor $\alpha(E R \alpha)$ and on the NPY cells through an estrogen-activated membrane receptor, Gq-mER [6]. Indeed, estradiol has an inhibitor function on food intake, repressing the synthesis of NPY and AgRP [7]. Moreover, it seems that the leptin (secreted by adipocytes in proportion to fat mass and the activator of anorexigenic signals) has a common pathway with estradiol to regulate energy metabolism, namely the STAT3 pathway in POMC neurons [7]. Peripherally $E_{2}$ increases both leptin mRNA expression in 3T3 adipocytes and leptin secretion in omental adipose tissue [8]. Alternatively, lack of $E_{2}$ after ovariectomy may affect body weight regulation at a central level and mice deficient in ER $\alpha$ show a marked increase of adipose tissue [9]. There is also some evidence that ovariectomy increases hypothalamic NPY expression and decreases CRH immunoreactivity, promoting hyperphagia [10]. Moreover, $\mathrm{E}_{2}$ deficiency causes central leptin insensitivity [9].

Endocrine-disrupting chemicals (EDCs) are industrial pollutants or natural molecules, which can be found as contaminants in the environment. They can interact with natural hormones by mimicking, antagonizing, or altering their actions [11] and may interfere with several brain circuits [12]. Recent evidence from many laboratories has shown that a variety of environmental EDCs (now called metabolic disrupting chemicals, MDCs) can influence adipogenesis and obesity and these effects may be partly mediated by sex steroid dysregulation due to the exposure to these substances and by alterations of nervous circuits involved in the control of food intake and energy metabolism [13,14].

In the present study, we analyzed three widely diffused MDCs-bisphenol A (BPA), diethylstilbestrol (DES), and tributyltin (TBT).

The BPA, one of the most diffused chemicals in the world, is a xenoestrogen present in a very large number of products and may affect multiple endocrine pathways, due to its ability to bind classical estrogen receptors (particularly ER- $\alpha$ ) and non-classical ones (membrane receptors) [15], as well as the G-protein-coupled receptor 30 (GPR30) [16]. BPA can also act through non-genomic pathways [17] and bind to a variety of other hormone receptors (e.g., androgen receptor, thyroid hormone receptor, glucocorticoid receptor, and PPAR $\gamma$ ) [18]. In vitro experiments have demonstrated that BPA may dysregulate NPY, AgRP, and POMC expression in hypothalamic immortalized cell lines [19-21].

The DES is a powerful nonsteroidal synthetic estrogen (pharmaceutical) used until the early 70s to prevent miscarriage in pregnant women. Later this compound was recognized as a cause of reproductive cancers, genital malformations, and infertility in sons or daughters that had been exposed to this drug in utero [22], but it is still in use for veterinary purposes in some countries and is bioaccumulated in the environment [23]. DES exerts an agonistic effect against ER- $\alpha$ and an antagonistic effect against estrogen-related receptor- $\gamma$ (ERR- $\gamma$ ) [24]. In ovariectomized female rats exposed to an isoflavone-rich diet, DES had no effect on hypothalamic NPY mRNA and increased POMC mRNA [25].

TBT belongs to the EDC family of organotins, it has been employed primarily as an antifouling agent in paint for boats. Other uses are as a fungicide on food crops, and an antifungal agent in wood treatments and industrial and textile water systems [26]. Due to its use in paint for boats, TBT has exerted toxicological effects on marine organisms. For example, TBT can induce masculinization in fish species [27]. Humans are exposed to TBT largely through contaminated dietary sources (seafood and shellfish [28]). In mammals TBT can increase body weight [29], alter hypothalamic NPY and POMC systems in short-term (4 weeks) exposed adult mice [30,31], and may also alter behavior-exposure to a low 
dose of TBT induced lower activity, high level of anxiety, and fear in mice [32]. TBT binds with high affinity to steroid receptors; in particular, it binds androgen receptor [33] and interferes with the expression of brain aromatase and estrogen receptors [34]. TBT can act as an agonist of retinoid $X$ receptor (RXR) and peroxisome proliferator-activated receptor- $\gamma$ $(\operatorname{PPAR} \gamma)$ [35]. This inappropriate receptor activation could lead to disruption of the normal developmental and homeostatic controls over adipogenesis and energy balance, especially under the influence of the typical high-fat Western diet [36]. In addition, changes in the microbiome are associated with TBT exposure [37].

As previously reported, studies on the action of EDC on hypothalamic neurons related to eating behavior and energy control used a variety of experimental conditions (exposure to isoflavones, in vitro experiments, and short-term exposure). For this reason, in the present study, we exposed, for a longer time period (4 months), adult male mice to phytoestrogen-free food containing different putative MDCs to understand if the central neuroendocrine, orexinergic, and anorexinergic circuits are differentially affected by these compounds. Due to the alleged xenoestrogenic activity of some of them we also included, as a positive control, a group of animals treated with $E_{2}$.

\section{Results}

\subsection{Body Weight}

At the end of the experiment the animals were weighted. Data collected showed a global effect of treatment on the body weight of exposed animals $\left(p<0.05, \mathrm{~F}_{(8)}=2.185\right)$. In particular, the post-hoc analysis with Fisher's LSD test showed a reduction in body weight for mice treated with the higher dose of DES $(p<0.05)$ and for those treated with both doses of $E_{2}(p<0.05)$. No statistically significant effects were observed in the other groups (see Table 1).

Table 1. Summary of statistical analysis of body weight data. The values (in grams) are indicated as mean \pm standard error of the mean (SEM). Bold numbers and asterisks indicate significant differences among the differently treated groups: ${ }^{*} p<0.05$, different from control $(p<0.05$, Fisher's test).

\begin{tabular}{ccc}
\hline Groups & $\begin{array}{c}\text { Body Weight (g) } \\
\text { Mean }+ \text { /-SEM }\end{array}$ & $p$ Value \\
\hline CRL & $31.2 \pm 2.92$ & \\
\hline TBT 0.5 & $31 \pm 0.89$ & 0.912 \\
\hline TBT 500 & $31.2 \pm 0.80$ & 1.000 \\
\hline DES 0.05 & $29.4 \pm 1.21$ & 0.323 \\
\hline DES 50 & $26.6 \pm 0.93$ & $0.015^{*}$ \\
\hline BPA 5 & $28.6 \pm 0.75$ & 0.156 \\
\hline BPA 500 & $29.6 \pm 0.93$ & 0.379 \\
\hline E2 5 & $26.75 \pm 0.48$ & $0.025^{*}$ \\
\hline E2 50 & $27.17 \pm 0.65$ & $0.025^{*}$ \\
\hline
\end{tabular}

\subsection{Immunohistochemistry}

\subsubsection{NPY System}

A preliminary qualitative analysis showed a distribution similar to those already reported in previous contributions [30,38-41]. In particular, we did not observe positive cell bodies (confirming previous reports that NPY cell bodies in ARC are visible only after colchicine treatment [42]), whereas a large number of positive fibers was observed along the entire hypothalamus. These were particularly dense within the PVN (Figure 1) and the ARC (Figure 2) nuclei, but they were also abundant within the suprachiasmatic, supraoptic, and DMH (Figure 2) nuclei. Other regions displayed less dense innervations, as for example, 
the VMH (Figure 2). In the experimental groups, we observed a qualitative decrease of the NPY immunoreactivity (ir) in all the considered nuclei for all the different treatments.
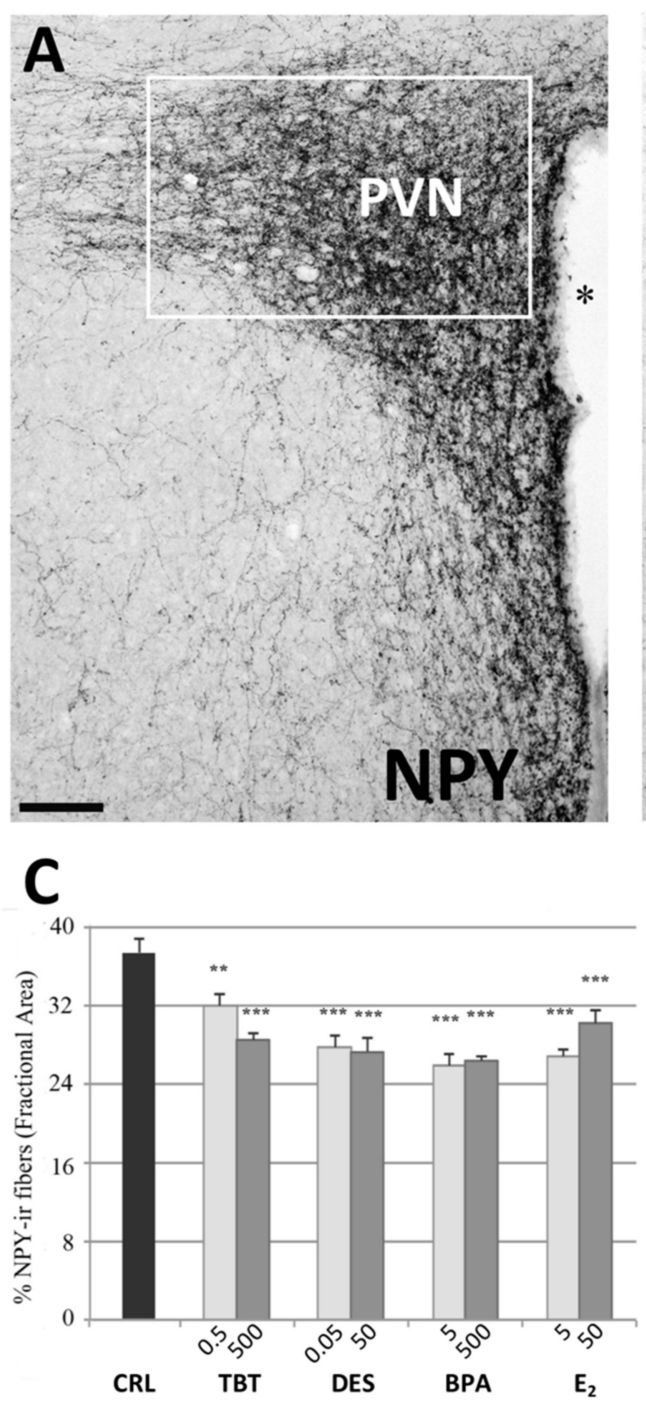

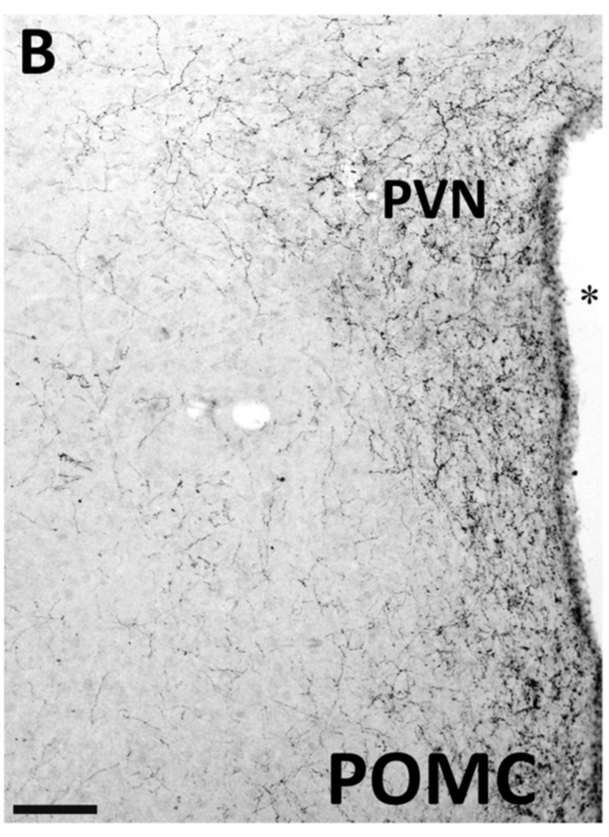

D

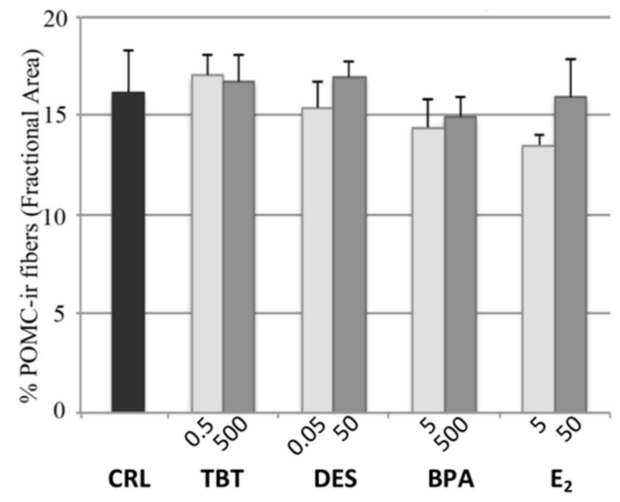

Figure 1. NPY and POMC immunohistochemistry in the PVN. Microphotographs and histograms illustrating the immunohistochemical immunoreactivity for NPY and POMC in the paraventricular nucleus (PVN). (A) Low magnification of a control mouse (CRL) illustrating the NPY immunoreactivity in PVN. The white box represent the ROI selected for the quantitative analysis. (B) Low magnification of a control mouse (CRL) illustrating the POMC immunoreactivity in PVN. Scale bar $=100 \mu \mathrm{m}$. * = Third ventricle. (C,D) Histograms illustrating the quantitative analysis of the fractional area covered by NPY (C) and POMC (D) immunoreactivity in the PVN. Bars represent the mean and the standard error of the mean (SEM). Asterisks indicate significant differences (Fisher's test) of the experimental groups in comparison to controls (CRL): ${ }^{* *} p<0.01{ }^{* * *} p<0.001$.

This qualitative impression was confirmed by the statistical analysis. For all nuclei we found a statistically significant effect of treatment (PVN: $p<0.001, \mathrm{~F}_{(8)}=10.672$; ARC: $p<0.01, \mathrm{~F}_{(8)}=3.566$; DMH: $\left.p<0.01, \mathrm{~F}_{(8)}=3.767 ; \mathrm{VMH}: p<0.001, \mathrm{~F}_{(8)}=5.780\right)$.

The post-hoc analysis with Fisher's LSD test showed a significant decrease of NPYir in all nuclei and for almost all the treatments. In PVN, all groups showed a significantly lower NPYir than controls $(p<0.01$, Figure 1$)$. In ARC, we did not observe statistically significant differences for the lowest dose of TBT and the highest dose of BPA, while all the other treatments induced a significant decrease of NPY expression $(p<0.05$, Figure 2$)$. In DMH we observed a significant reduction of NPYir in all treated groups $(p<0.05$; Figure 2$)$, 
except for the lowest dose of DES. Finally, in VMH we observed a strong reduction of NPYir due to the treatments $(p<0.01)$ except for the highest dose of TBT (for details see Table S2, Supplementary Materials).
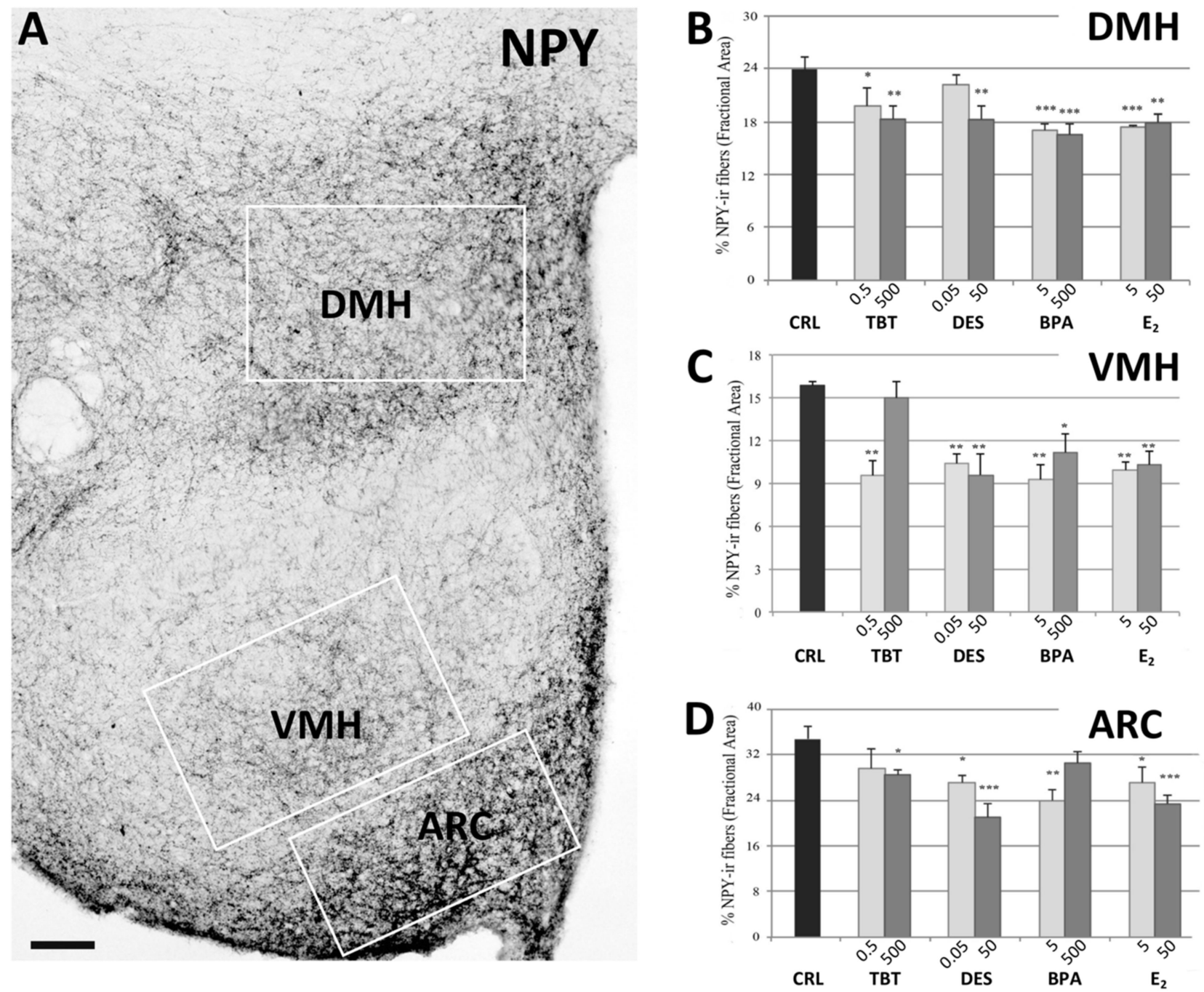

Figure 2. NPY immunohistochemistry. Microphotograph and histograms illustrating the immunohistochemical immunoreactivity for NPY in the dorsomedial (DMH), ventromedial (VMH), and arcuate (ARC) nuclei. (A) Low magnification of the hypothalamic region of a control mouse (CRL) illustrating the NPY immunoreactivity in DMH, VMH, and ARC nuclei. The white boxes represent the ROI selected for each nucleus in the quantitative analysis. Scale bar $=100 \mu \mathrm{m}$. (B-D) Histograms illustrating the quantitative analysis of the fractional area covered by NPY immunoreactivity in the DMH (B), VMH (C), and ARC (D) nuclei in the different experimental groups. Bars represent the mean and the standard error of the mean (SEM). Asterisks indicate significant differences (Fisher's test) of the experimental groups in comparison to controls (CRL): ${ }^{*} p<0.05,{ }^{* *} p<0.01,{ }^{* * *} p<0.001$.

\subsubsection{POMC System}

The distribution of POMCir in control mice was in agreement with the few previous studies that described this system in rats [43-45] and mice [31,46]. Contrary to NPY, hypothalamic POMC cell bodies are clearly visible, and they were fully included within the rostrocaudal extent of the ARC (Figure 3) and periarcuate area, which also showed a local dense innervation of ir fibers. Two major targets of this system are the PVN and the DMH. In the PVN, POMCir fibers outlined the entire nucleus, starting from its rostral portion up to the more caudal levels. The distribution of these fibers was not homogeneous, in particular they were denser in the medial PVN (corresponding to the parvocellular regions 
of this nucleus) compared to the lateral PVN (corresponding to the magnocellular region) (Figure 1). The DMH nucleus (Figure 3) showed a denser innervation in the caudal part of the nucleus compared with the rostral part. Other hypothalamic nuclei, such as the VMH, did not show a significant number of positive fibers.
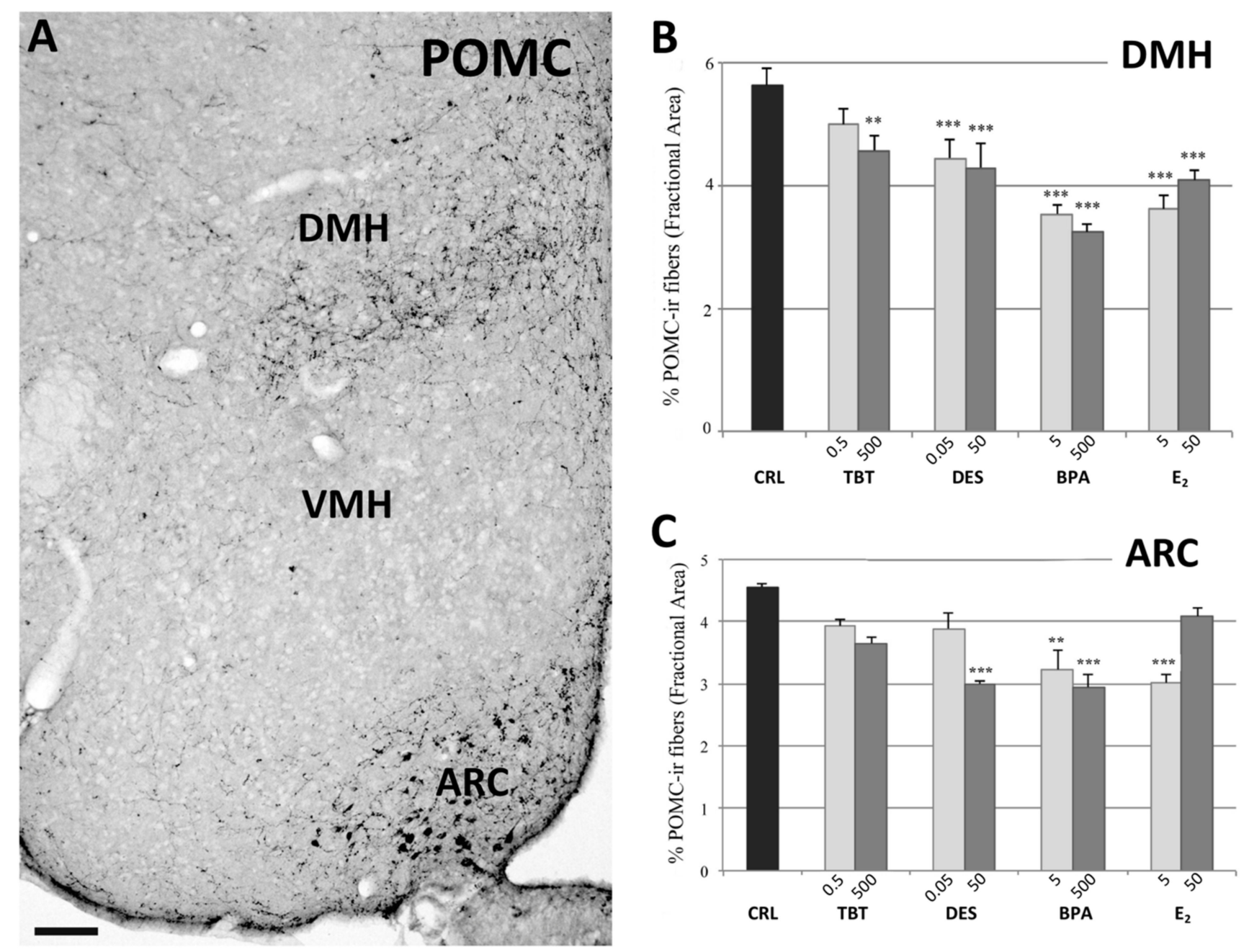

Figure 3. POMC immunohistochemistry. Microphotograph and histograms illustrating the immunohistochemical immunoreactivity for POMC in the dorsomedial (DMH), and arcuate (ARC) nuclei. (A) Low magnification of the hypothalamic region of a control mouse (CRL) illustrating the POMC immunoreactivity in DMH, and ARC nuclei. Due to the extreme paucity of immunoreactive structures, it was not possible to measure POMC immunoreactivity in the VMH. Scale bar $=100 \mu \mathrm{m}$. (B,C) Histograms illustrating the quantitative analysis of the fractional area covered by POMC immunoreactivity in the DMH (B), and ARC (C) nuclei in the different experimental groups. Bars represent the mean and the standard error of the mean (SEM). Asterisks indicate significant differences (Fisher's test) of the experimental groups in comparison to controls (CRL): ${ }^{* *} p<0.01,{ }^{* * *} p<0.001$.

In the PVN we did not observe variations due to treatment. In fact, the statistical analysis showed no effect of treatment $(\mathrm{F}=1.097, p=0.396$, Figure 1). On the contrary, data collected in the ARC showed a decrease of the POMCir (including positive cell bodies and fibers), following the different treatments $\left(\mathrm{F}_{(8)}=8.289, p<0.001\right)$. The Fisher LSD test showed a statistically significant decrease in the groups treated with the highest dose of DES $(p<0.001)$, the lowest of $\mathrm{E}_{2}(p<0.001)$ and in both groups treated with BPA $(p<0.001$, Figure 3).

The quantitative analysis also showed a decrease of the POMCir in the DMH following different treatments $\left(\mathrm{F}_{(8)}=19.563, p<0.001\right)$. The Fisher LSD test showed a decrease of 
POMC ir in all groups compared to controls, except for the lowest dose of TBT (Figure 3; for details see Table S2, Supplementary Materials).

\section{Discussion}

The control of energy metabolism and food intake is in part dependent on central neuroendocrine circuits that have been detailed in the introduction. Among the various systems, the NPY and the POMC systems (both located in the hypothalamic arcuate nucleus and sending their axons to other hypothalamic nuclei) exert orexigenic (NPY) and anorexigenic (POMC) effects. Several studies (recently reviewed by [14]) demonstrated that these neural circuits are altered when the animals are exposed to some environmental compounds that are now classified as metabolism-disrupting chemicals (MDCs) [13,47].

In the present study, we showed that some of the putative MDCs, when chronically administered through a phytoestrogen-free diet (reported in the literature as inducing body weight gain [48]), affected the expression of both NPY and POMC in the hypothalamic circuits of adult male mice. For comparison, we included two additional groups, one without any treatment (control group) and the second one exposed to $E_{2}$ (added to the diet), which has a well-known anti-adipogenic effect [49,50].

As expected, in the present experiment, both doses of $E_{2}$ induced a significant reduction of the body weight in comparison to the control group. On the contrary, male mice fed with the same diet but with different concentrations of three different EDCs, except the group treated with the highest dose of DES, did not show any significant reduction of the body weight. These results suggest that BPA, DES, and TBT are not able, in adult male mice, to counteract the consequence of an exposure to a phytoestrogen-free diet on the body weight, whereas $E_{2}$ is able to do this. Therefore, whereas $E_{2}$ has an anti-obesogenic effect, the EDCs considered in this study do not show this property. It is possible that the lack of effect on body weight is due to the fact that the reduction of the activity of the orexinergic circuits originated by the reduction of NPY is compensated by the reduction of the activity of the anorexinergic circuits caused by the reduction of the expression of POMC.

Our data show that the NPY expression in male mice hypothalamic nuclei involved in food intake regulation is reduced by $\mathrm{E}_{2}$ as well as by all tested EDCs at almost all doses. Therefore DES, BPA, and TBT have the same effect of $E_{2}$ on the NPY system. In particular, DES and BPA have a well-known strong xenoestrogenic activity because they specifically bind to ERs [51]. On the contrary, TBT does not bind ERs, but it also has xenoandrogenic or antiandrogenic activity [52]. The reduction of NPY expression in the hypothalamus after TBT treatment confirms our previous results [30] and may be due to the activation of other pathways, not directly regulated by $\mathrm{E}_{2}$.

The effects of treatments on the POMC system of male mice are less homogeneous. In fact, we observed significant effects on ARC and DMH, while in the PVN we have not detected significant effects. DES, BPA, and also $\mathrm{E}_{2}$ significantly decreased the POMC expression in ARC, while TBT showed no significant effect. It is important to note that $30 \%$ of POMC cells in ARC colocalize with ER $\alpha$ while they do not express ER $\beta$ [53], thus suggesting a possible direct role of ERs in regulating part of this system that represents, consequently, a putative target for xenoestrogens, like BPA and DES. The lack of TBT effect is also in line with our recent results that showed no effects of TBT on the POMC system in adult male mice [31].

The POMC neurons of the ARC send axons to two main targets, the DMH and the PVN. All treatments (including TBT at the highest dose) induced a significant decrease in the immunoreactivity in the DMH, whereas no effect was detected in the PVN, even when the quantitative analysis was performed on the different parts of the PVN, according to the method detailed in [54] (results summarized in Figure S3 of Supplementary Material). It is still possible that the paucity of POMC fibers in the PVN (compared to the NPY ones) has prevented the detection of small differences in the present experimental material.

In a limited number of experimental groups, the tested EDCs showed a significant effect in reducing immunoreactivity at the low dose and not at the high dose, for example 
see the effect of TBT on VMH NPY immunoreactivity, the effect of BPA on ARC NPY immunoreactivity, or the effect of $E_{2}$ on ARC POMC immunoreactivity. These results confirm the nonmonotonic dose response described in many experimental situations for several EDCs [55]. The differences of the results of EDC treatments on NPY and POMC immunoreactivity with those obtained with $E_{2}$, are probably due to the activation of pathways not directly or indirectly regulated by $E_{2}$. For example, it has been found that intracerebroventricular injections of oxytocin (OT) in adult fasted male rats decreases food intake [56]. Moreover, a retrograde tracer study revealed OT projection from PVN and SON to ARC, demonstrating that oxytocinergic signaling may regulate feeding [57]. OT cells, expressing ER- $\beta$, of the PVN [58], are a possible target for xenoestrogen that binds ER- $\beta$, like the phytoestrogen genistein [59]. This suggests that some EDCs may alter POMC expression via the OT system. However, the physiological significance of the OT neuronal projections from PVN and SON to ARC POMC neurons, still remains unclear, and further studies are required to clarify it.

One of the most important regulators of the NPY [60] and POMC [61] systems is represented by the cannabinoid receptor CB1. Some EDCs may modulate the expression of this receptor: prolonged exposure to DES produced a reduction in the mRNA for CB1 receptor in the rat pituitary [62], while BPA caused a downregulation of CB1 receptor in the mice hypothalamus [63]. No data are yet available for an action of TBT on the expression of CB1 receptor. Therefore, it is possible that present results on the alterations of NPY and POMC systems are partly due to an effect of the EDCs on the expression of CB1 receptor and a consequent functional alteration of these two systems. Future work should clarify this aspect.

The levels of circulating glucose are also important in controlling the NPY and POMC circuits, through glucose sensitive neurons located in the VMH and LH (for a recent review see [64]). All the three EDCs analyzed in this study disrupt glucose homeostasis by acting on pancreatic islets $[37,65,66]$. Even if in the present study we have not detected glucose blood levels, it is therefore possible that part of the dysregulation of the NPY and POMC systems is due to alterations of glucose homeostasis.

Another crucial point is that we do not know, at the moment, if we are observing an activational or an organizational effect of these EDCs. In the first case we may expect that the differences in the expression of immunoreactivity are due to an increase or a decrease in the production of neuropeptides in stable circuits (see the effects of BPA on NPY mRNA in neuronal cell cultures [20]). In the second case the hypothesis is that the exposure to the EDCs may induce permanent (or long-term) changes in the observed circuits. In fact, it has been demonstrated that gonadal hormones produced during puberty are inducing neurogenesis in some hypothalamic [67] or extrahypothalamic [68] nuclei and that this process is necessary to stabilize the sexual differences evidenced in these nuclei. A recent review [69] analyzed the available data for the development of hypothalamic circuits that control food intake and energy balance. In summary, in these circuits neurogenesis is only present during the prenatal period [70], but the full maturation of the connections ARC-PVN is reached during the postnatal days 28-35 [71]. However, more recent studies demonstrated that adult neurogenesis of NPY and POMC neurons in mice ARC is stimulated by changes among high fat-low fat diets [72]. Being our animal was three weeks old, it is therefore possible that exposure to EDCs had altered the connection of ARC towards VMH, DMH, and PVN, or even determined a change in the number of NPY and POMC neurons (BPA may induce apoptosis in hippocampal cells [73]). According to this hypothesis the observed changes in the immunoreactivity could be linked to an alteration (plasticity) of fibers' system reaching these nuclei. At the moment it is impossible to know if NPY and POMC circuits, after such a long exposure to EDCs, when provided with EDCs-free food, may recover to a status comparable to the non-treated animals (this is compatible with an activational effect). Future studies should elucidate this point, in particular not only if there is a recovery, but also how long it will take to recover. 
In conclusion, these data, together with those already present in the literature, suggest that EDCs may alter energy metabolism not only at the level of peripheral tissues [13], but also in neuroendocrine circuits involved in the control of food intake, in particular, the NPY and POMC systems. The control of physiological processes by these systems is highly complex, making the understanding of neuroendocrine disruption a particular challenge.

\section{Materials and Methods}

\subsection{Animals and Treatment}

The procedures involving animals and their care were performed in Brescia according to the Union Council Directive of 22 September 2010 (2010/63/UE). The study was approved by the Ethical Committee of Animal Experimentation of the Hospital and the Italian Minister of Health (407/2018-PR). All care was taken to use the minimum number of animals.

C57BJ/ 6 male mice (Harlan, Udine) were housed in same-sex groups of 4 per cage on a 12:12-h light/dark cycle; animal rooms were maintained at a temperature of $23^{\circ} \mathrm{C}$. Estrogen-free diet was purchased from Dottori Piccioni S.r.L. Via Guglielmo Marconi, 29/31 Gessate (MI, Italy) (https: / / totofood.it/, assessed on 7 June 2021). The diet was prepared in pellets (the composition is reported in Table S1, Supplementary Materials).

The treatment started when mice were three weeks old and lasted for four months. Animals were divided randomly in nine experimental groups: control mice were fed with the base diet (estrogen-free diet) while experimental groups were fed with the base diet enriched with two different concentrations of $E_{2}$, BPA, DES, or TBT (according to previous studies [74]). All the chemicals were obtained from Sigma-Aldrich, Milano, Italy, dissolved in DMSO and further diluted before their addition to the diet, for homogeneous preparations. These are the doses used: $\mathrm{E}_{2}$ (stock solution $97 \%$, cat. number E8515; 5 or $50 \mu \mathrm{g} / \mathrm{kg}$ diet); BPA (stock solution $99 \%$, cat. number $239658 ; 5$ or $500 \mu \mathrm{g} / \mathrm{kg}$ diet); DES (stock solution $99 \%$, cat. number D-4628; 0.05 or $50 \mu \mathrm{g} / \mathrm{kg}$ diet); and TBT (stock solution $96 \%$, cat. number T50202; 0.5 or $500 \mu \mathrm{g} / \mathrm{kg}$ diet).

The normal food consumption in adult mice corresponds to $15 \mathrm{~g} / 100 \mathrm{~g}$ body weight/day [75]; since mice used in this experiment had a mean body weight of $30 \mathrm{~g}$, it was considered an approximate consumption of $4.5 \mathrm{~g}$ food/day was appropriate. Accordingly, in this case mice were exposed daily to approximately $0.15-1.5 \mu \mathrm{g} / \mathrm{g}$ body weight of $\mathrm{E}_{2}, 0.15-15 \mu \mathrm{g} / \mathrm{g}$ body weight of BPA, $0.0015-1.5 \mu \mathrm{g} / \mathrm{g}$ body weight of DES, and $0.015-15 \mu \mathrm{g} / \mathrm{g}$ body weight of TBT.

Body weights were recorded at the end of the experiment, before sacrifice (see Table 1).

Food consumption was monitored every two days as the difference between the weight of the pellets supplied and that consumed. Spilled food, if any, was collected in apposite trays underneath the food containers, measured, and taken into account.

\subsection{Tissue Sampling and Histological Examination}

Four months after the beginning of treatment adult mice were deeply anesthetized with an intraperitoneal injection of a mixture of ketamine $(100 \mathrm{mg} / \mathrm{kg}$ of body weight, Ketavet, Gelling, Italy) and xylazine (10 mg/kg of body weight, Rompun, Bayer, Germany) solution, monitored until the pedal reflex was abolished and killed by cervical dislocation. Animals were decapitated, brains were quickly dissected and placed into acrolein (5\% in $0.01 \mathrm{M}$ saline phosphate buffer, PBS) for $150 \mathrm{~min}$ at room temperature. Brains were rinsed several times in PBS, placed overnight in a $30 \%$ sucrose solution in PBS at $4{ }^{\circ} \mathrm{C}$, frozen in liquid isopentane at $-40^{\circ} \mathrm{C}$ and stored in a deep freezer at $-80^{\circ} \mathrm{C}$ until sectioning.

Brains ( $\mathrm{N}=4$ for each group) were serially cut in the coronal plane with a cryostat (Leica CM 1900) at $25 \mu \mathrm{m}$ of thickness. Sections were collected in four series for freefloating procedure in multiwell dishes, filled with a cryoprotectant solution [76] and stored at $-20{ }^{\circ} \mathrm{C}$ until used for immunohistochemistry. One series of sections was stained for NPY immunohistochemistry and another for POMC immunohistochemistry. Brain sections 
were always stained in groups containing each treatment, so that between-assay variance could not cause systematic group differences.

After overnight washing in PBS, sections were incubated in $0.01 \%$ sodium borohydride for $20 \mathrm{~min}$ to remove the acrolein and rinsed in PBS several times. Then, sections were exposed to Triton X-100 ( $0.2 \%$ in PBS) for $30 \mathrm{~min}$ and treated for blocking endogenous peroxidase activity with PBS solution containing methanol/hydrogen peroxide for $20 \mathrm{~min}$. Sections were afterwards incubated with normal goat serum (Vector Laboratories, Burlingame, CA, USA) for $30 \mathrm{~min}$. One series was incubated overnight at $4{ }^{\circ} \mathrm{C}$ with the rabbit polyclonal antibody against synthetic porcine NPY (gift by Professor Vaudry, France) diluted 1:5000 in 0.2\% PBS-Triton X-100, pH 7.3-7.4 and another with the rabbit polyclonal antibody against POMC (Phoenix Pharmaceuticals, Inc.,Burlingame, CA USA) $[31,77,78]$ diluted 1:5000 in $0.2 \%$ PBS-Triton X-100 and $1 \%$ of BSA, $\mathrm{pH}$ 7.3-7.4. The next day, sections were incubated for $60 \mathrm{~min}$ in biotinylated goat anti-rabbit IgG (Vector Laboratories, Burlingame, CA, USA) 1:200. The antigen-antibody reaction was revealed by $60 \mathrm{~min}$ incubation with the biotin-avidin system (Vectastain ABC Kit Elite, Vector Laboratories, Burlingame, CA, USA). The peroxidase activity was visualized with a solution containing $0.400 \mathrm{mg} / \mathrm{mL}$ of 3,3'-diamino-benzidine (DAB, Sigma-Aldrich, Milano, Italy) and $0.004 \%$ hydrogen peroxide in $0.05 \mathrm{M}$ Tris- $\mathrm{HCl}$ buffer, $\mathrm{pH}$ 7.6. Sections were mounted on chromallum-coated slides, air-dried, cleared in xylene, and cover slipped with Entellan (Merck, Milano, Italy).

The production and characterization of NPY polyclonal antibody has been previously reported $[79,80]$ and it has been employed to detect the NPY system in a wide range of species [40].

The POMC antibody from Phoenix Pharmaceuticals recognizes a sequence corresponding to $\mathrm{N}$ terminal amino acids 27-52 of Pig POMC precursor and has often been used in mouse and rat studies [31,42,81].

We performed the following additional controls in our material: (a) the primary antibody was omitted or replaced with an equivalent concentration of normal serum (negative controls) and (b) the secondary antibody was omitted. In these conditions, cells and fibers were completely unstained.

\subsection{Quantitative Analysis}

All sections were acquired with a NIKON Digital Sight DS-Fi1 video camera connected to a NIKON Eclipse 80i microscope (Nikon Italia S.p.S., Firenze, Italy). The staining density of NPY- and POMC-immunoreactive (ir)-containing structures was measured in selected nuclei with the freeware Image (version 1.49b, Wayne Rasband, NIH, Bethesda, MD, USA) by calculating in binary transformations of the images (threshold function) the fractional area (percentages of pixels) covered by immunoreactive structures in predetermined fields (area of interest, ROI). Due to differences in the immunostaining, according to our previous reports [50,63], the range of the threshold was individually adjusted for each section.

For quantification of NPY and POMC systems we selected four hypothalamic nuclei involved in controlling food intake-ARC, DMH, PVN, and ventromedial hypothalamic nucleus (VMH). For each nucleus, we measured the density of immunoreactive structures on three consecutive sections identified by the Mouse Brain Atlas (ARC, VMH, DMH: bregma $-1.46 \mathrm{~mm},-1.58 \mathrm{~mm},-1.70 \mathrm{~mm}$; PVN: bregma $-0.70 \mathrm{~mm},-0.82 \mathrm{~mm},-0.94 \mathrm{~mm}[82,83]$.

The ROI selected for each nucleus was a box of fixed size and shape, selected to cover immunoreactive material only within the boundaries of each nucleus (about $140,000 \mu^{2}$ for VMH and DMH, 110,000 $\mu^{2}$ for ARC, and 200,000 $\mu^{2}$ for PVN). Due to the extreme paucity of immunoreactive structures, it was not possible to measure POMCimmunoreactivity in the VMH.

\subsection{Statistical Analysis}

Collected data were analyzed with the program SPSS 24.0 (SPSS Inc., Chicago, IL, USA); the $p$ values and the significance threshold were set at $p \leq 0.05$. Data collected for 
the body weight were analyzed by one-way ANOVA followed by post-hoc analysis with a Fisher LSD test. Data collected for the immunohistochemistry were analyzed by repeatedmeasure one-way ANOVA. When the analysis did not show significant differences between different levels of the same nucleus, we calculated a mean value for each nucleus that was used to assess variations due to the treatment. When statistically significant, the ANOVA analysis was followed by a Fisher LSD test.

Supplementary Materials: The following are available online at https://www.mdpi.com/article/10 .3390/metabo11060368/s1, Figure S1: NPY immunoreactivity. Immunohistochemical comparison of NPY immunoreactivity among control animals (CRL) and the different treated groups (in all case it was shown to be the lowest dose used) in the dorsomedial (DMH), ventromedial (VMH), arcuate (ARC), and paraventricular (PVN) nuclei. Estradiol, E2; tributyltin, TBT; diethylstilbestrol, DES; bisphenol A, BPA. Scale bar $=100 \mu \mathrm{m}$, Figure S2: POMC immunoreactivity. Immunohistochemical comparison of POMC immunoreactivity among control animals (CRL) and the different treated groups (in all case it was shown to be the lowest dose used) in the dorsomedial (DMH), arcuate (ARC), and paraventricular (PVN) nuclei. Estradiol, E2; tributyltin, TBT; diethylstilbestrol, DES; bisphenol A, BPA. Scale bar $=100 \mu \mathrm{m}$, Figure S3: Regional analysis of POMC immunoreactivity in the PVN. To further confirm the absence of variations in the POMC expression within the PVN, we measured the immunoreactivity, according to our previous studies [54], by dividing the PVN into four quadrants: dorsomedial (DM), dorsolateral (DL), ventromedial (VM), and ventrolateral (VL). The results of this analysis reported no significant differences for all the analyzed subregions and are summarized in the histograms $(B-E)$. Scale bar $=100 \mu \mathrm{m}$, Table S1. Composition of the soy-free diet (SFSD), Table S2. Summary of quantitative analysis of the fractional area. Fractional area data in the different nuclei and in the different groups analyzed in this study. The values reported are the mean and standard error of the mean (SEM). Bold numbers and asterisks indicate significant differences (Fisher's test) among the differently treated groups: ${ }^{*} p<0.05,{ }^{* *} p<0.01,{ }^{* * *} p<0.001$ different from control.

Author Contributions: M.M. and E.B. performed experiments, analyzed data, and wrote the paper. E.C., A.F., G.P. (Giovanna Ponti), and I.Z. performed the experiments. D.D.L., G.C.P. (GianCarlo Panzica), and S.G. designed experiments, and wrote and supervised the paper. D.D.L. and I.Z. hosted, maintained, and treated the mice until sacrifice. All authors have read and agreed to the published version of the manuscript.

Funding: This work was supported by European Union Grants QLK4-CT-2002-02221 (EDERA) and LSHB-CT-2006-037168 (EXERA), Ministero dell'Istruzione, dell'Università e della Ricerca-MIUR project Dipartimenti di Eccellenza 2018-2022 to Department of Neuroscience Rita Levi Montalcini; University of Torino, Ricerca locale to GP, GCP, SG, and Cavalieri-Ottolenghi Foundation, Orbassano, Italy.

Institutional Review Board Statement: The study was performed in Brescia according to the Union Council Directive of 22 September 2010 (2010/63/UE); The study was approved by the Ethical Committee of Animal Experimentation of the Hospital and the Italian Minister of Health $(407 / 2018$ PR, 02/06/2018).

Informed Consent Statement: Not applicable.

Data Availability Statement: All the data are available from the authors upon reasonable request. The data presented in this study are available in this supplementary.

Acknowledgments: MM was a fellow of G.C. Bergui (2020) and is now a fellow of the Fondazione Umberto Veronesi (2021).

Conflicts of Interest: The authors declare no conflict of interest.

\section{References}

1. Broberger, C. Brain regulation of food intake and appetite: Molecules and networks. J. Intern. Med. 2005, 258, 301-327. [CrossRef]

2. Kalra, S.P.; Dube, M.G.; Pu, S.; Xu, B.; Horvath, T.L.; Kalra, P.S. Interacting appetite-regulating pathways in the hypothalamic regulation of body weight. Endocr. Rev. 1999, 20, 68-100. [CrossRef]

3. Grun, F.; Blumberg, B. Endocrine disrupters as obesogens. Mol. Cell Endocrinol. 2009, 304, 19-29. [CrossRef]

4. Clegg, D.J. Minireview: The year in review of estrogen regulation of metabolism. Mol. Endocrinol. 2012, 26, 1957-1960. [CrossRef] 
5. Stincic, T.L.; Ronnekleiv, O.K.; Kelly, M.J. Diverse actions of estradiol on anorexigenic and orexigenic hypothalamic arcuate neurons. Horm. Behav. 2018, 104, 146-155. [CrossRef] [PubMed]

6. Roepke, T.A.; Bosch, M.A.; Rick, E.A.; Lee, B.; Wagner, E.J.; Seidlova-Wuttke, D.; Wuttke, W.; Scanlan, T.S.; Ronnekleiv, O.K.; Kelly, M.J. Contribution of a membrane estrogen receptor to the estrogenic regulation of body temperature and energy homeostasis. Endocrinology 2010, 151, 4926-4937. [CrossRef] [PubMed]

7. Gao, Q.; Horvath, T.L. Cross-talk between estrogen and leptin signaling in the hypothalamus. Am. J. Physiol. Endocrinol. Metab. 2008, 294, E817-E826. [CrossRef]

8. Casabiell, X.; Pineiro, V.; Peino, R.; Lage, M.; Camina, J.; Gallego, R.; Vallejo, L.G.; Dieguez, C.; Casanueva, F.F. Gender differences in both spontaneous and stimulated leptin secretion by human omental adipose tissue in vitro: Dexamethasone and estradiol stimulate leptin release in women, but not in men. J. Clin. Endocrinol. Metab. 1998, 83, 2149-2155. [CrossRef]

9. Ainslie, D.A.; Morris, M.J.; Wittert, G.; Turnbull, H.; Proietto, J.; Thorburn, A.W. Estrogen deficiency causes central leptin insensitivity and increased hypothalamic neuropeptide Y. Int. J. Obes. 2001, 25, 1680-1688. [CrossRef]

10. Shimizu, H.; Ohtani, K.; Kato, Y.; Tanaka, Y.; Mori, M. Withdrawal of estrogen increases hypothalamic neuropeptide Y (NPY) mRNA expression in ovariectomized obese rat. Neurosci. Lett. 1996, 204, 81-84. [CrossRef]

11. La Merrill, M.A.; Vandenberg, L.N.; Smith, M.T.; Goodson, W.; Browne, P.; Patisaul, H.B.; Guyton, K.Z.; Kortenkamp, A.; Cogliano, V.J.; Woodruff, T.J.; et al. Consensus on the key characteristics of endocrine-disrupting chemicals as a basis for hazard identification. Nat. Rev. Endocrinol. 2020, 16, 45-57. [CrossRef]

12. Panzica, G.C.; Bo, E.; Martini, M.A.; Miceli, D.; Mura, E.; Viglietti-Panzica, C.; Gotti, S. Neuropeptides and enzymes are targets for the action of endocrine disrupting chemicals in the vertebrate brain. J. Toxicol. Environ. Health Part B 2011, 14, 449-472. [CrossRef] [PubMed]

13. Heindel, J.J.; Blumberg, B.; Cave, M.; Machtinger, R.; Mantovani, A.; Mendez, M.A.; Nadal, A.; Palanza, P.; Panzica, G.; Sargis, R.; et al. Metabolism disrupting chemicals and metabolic disorders. Reprod. Toxicol. 2017, 68, 3-33. [CrossRef] [PubMed]

14. Marraudino, M.; Bonaldo, B.; Farinetti, A.; Panzica, G.; Ponti, G.; Gotti, S. Metabolism Disrupting Chemicals and Alteration of Neuroendocrine Circuits Controlling Food Intake and Energy Metabolism. Front. Endocrinol. 2018, 9, 766. [CrossRef]

15. Alonso-Magdalena, P.; Laribi, O.; Ropero, A.B.; Fuentes, E.; Ripoll, C.; Soria, B.; Nadal, A. Low doses of bisphenol A and diethylstilbestrol impair $\mathrm{Ca} 2+$ signals in pancreatic alpha-cells through a nonclassical membrane estrogen receptor within intact islets of Langerhans. Environ. Health Perspect. 2005, 113, 969-977. [CrossRef]

16. Thomas, P.; Dong, J. Binding and activation of the seven-transmembrane estrogen receptor GPR30 by environmental estrogens: A potential novel mechanism of endocrine disruption. J. Steroid Biochem. Mol. Biol. 2006, 102, 175-179. [CrossRef]

17. Ropero, A.B.; Alonso-Magdalena, P.; Ripoll, C.; Fuentes, E.; Nadal, A. Rapid endocrine disruption: Environmental estrogen actions triggered outside the nucleus. J. Steroid Biochem. Mol. Biol. 2006, 102, 163-169. [CrossRef]

18. MacKay, H.; Abizaid, A. A plurality of molecular targets: The receptor ecosystem for bisphenol-A (BPA). Horm. Behav. 2017. [CrossRef] [PubMed]

19. Loganathan, N.; Salehi, A.; Chalmers, J.A.; Belsham, D.D. Bisphenol A Alters Bmal1, Per2, and Rev-Erba mRNA and Requires Bmal1 to Increase Neuropeptide Y Expression in Hypothalamic Neurons. Endocrinology 2019, 160, 181-192. [CrossRef]

20. Loganathan, N.; Mcllwraith, E.K.; Belsham, D.D. BPA Differentially Regulates NPY Expression in Hypothalamic Neurons Through a Mechanism Involving Oxidative Stress. Endocrinology 2020, 161. [CrossRef] [PubMed]

21. Loganathan, N.; McIlwraith, E.K.; Belsham, D.D. Bisphenol A induces Agrp gene expression in hypothalamic neurons through a mechanism involving ATF3. Neuroendocrinology 2020. [CrossRef] [PubMed]

22. Goldberg, J.M.; Falcone, T. Effect of diethylstilbestrol on reproductive function. Fertil. Steril. 1999, 72, 1-7. [CrossRef]

23. Tapiero, H.; Nguyen Ba, G.; Tew, K.D. Estrogens and environmental estrogens. Biomed. Pharmacother. 2002, 56, 36-44. [CrossRef]

24. Nam, K.; Marshall, P.; Wolf, R.M.; Cornell, W. Simulation of the different biological activities of diethylstilbestrol (DES) on estrogen receptor alpha and estrogen-related receptor gamma. Biopolymers 2003, 68, 130-138. [CrossRef] [PubMed]

25. Zhang, Y.B.; Zhang, Y.; Li, L.N.; Zhao, X.Y.; Na, X.L. Soy isoflavone and its effect to regulate hypothalamus and peripheral orexigenic gene expression in ovariectomized rats fed on a high-fat diet. Biomed. Environ. Sci. 2010, 23, 68-75. [CrossRef]

26. Zuo, Z.; Chen, S.; Wu, T.; Zhang, J.; Su, Y.; Chen, Y.; Wang, C. Tributyltin causes obesity and hepatic steatosis in male mice. Environ. Toxicol. 2011, 26, 79-85. [CrossRef]

27. McAllister, B.G.; Kime, D.E. Early life exposure to environmental levels of the aromatase inhibitor tributyltin causes masculinisation and irreversible sperm damage in zebrafish (Danio rerio). Aquat. Toxicol. 2003, 65, 309-316. [CrossRef]

28. Golub, M.; Doherty, J. Triphenyltin as a potential human endocrine disruptor. J. Toxicol. Environ. Health B Crit. Rev. 2004, 7 , 281-295. [CrossRef]

29. Si, J.; Wu, X.; Wan, C.; Zeng, T.; Zhang, M.; Xie, K.; Li, J. Peripubertal exposure to low doses of tributyltin chloride affects the homeostasis of serum T, E2, LH, and body weight of male mice. Environ. Toxicol. 2011, 26, 307-314. [CrossRef]

30. Bo, E.; Farinetti, A.; Marraudino, M.; Sterchele, D.; Eva, C.; Gotti, S.; Panzica, G. Adult exposure to tributyltin affects hypothalamic neuropeptide Y, Y1 receptor distribution, and circulating leptin in mice. Andrology 2016, 4, 723-734. [CrossRef] [PubMed]

31. Farinetti, A.; Marraudino, M.; Ponti, G.; Panzica, G.; Gotti, S. Chronic treatment with tributyltin induces sexually dimorphic alterations in the hypothalamic POMC system of adult mice. Cell Tissue Res. 2018, 374, 587-594. [CrossRef] 
32. Ohtaki, K.; Aihara, M.; Takahashi, H.; Fujita, H.; Takahashi, K.; Funabashi, T.; Hirasawa, T.; Ikezawa, Z. Effects of tributyltin on the emotional behavior of C57BL/ 6 mice and the development of atopic dermatitis-like lesions in DS-Nh mice. J. Dermatol. Sci. 2007, 47, 209-216. [CrossRef]

33. Yamabe, Y.; Hoshino, A.; Imura, N.; Suzuki, T.; Himeno, S. Enhancement of androgen-dependent transcription and cell proliferation by tributyltin and triphenyltin in human prostate cancer cells. Toxicol. Appl. Pharmacol. 2000, 169, 177-184. [CrossRef]

34. Zhang, J.; Zuo, Z.; Zhu, W.; Sun, P.; Wang, C. Sex-different effects of tributyltin on brain aromatase, estrogen receptor and retinoid $X$ receptor gene expression in rockfish (Sebastiscus marmoratus). Mar. Environ. Res. 2013, 90, 113-118. [CrossRef] [PubMed]

35. Nakanishi, T. Endocrine disruption induced by organotin compounds; organotins function as a powerful agonist for nuclear receptors rather than an aromatase inhibitor. J. Toxicol. Sci. 2008, 33, 269-276. [CrossRef]

36. Grun, F.; Blumberg, B. Environmental obesogens: Organotins and endocrine disruption via nuclear receptor signaling. Endocrinology 2006, 147, S50-S55. [CrossRef]

37. Zhan, J.; Ma, X.; Liu, D.; Liang, Y.; Li, P.; Cui, J.; Zhou, Z.; Wang, P. Gut microbiome alterations induced by tributyltin exposure are associated with increased body weight, impaired glucose and insulin homeostasis and endocrine disruption in mice. Environ. Pollut. 2020, 266, 115276. [CrossRef] [PubMed]

38. Oberto, A.; Mele, P.; Zammaretti, F.; Panzica, G.C.; Eva, C. Evidence of Altered Neuropeptide Y Content and Neuropeptide Y1 Receptor Gene Expression in the Hypothalamus of Pregnant Transgenic Mice. Endocrinology 2003, 144, 4826-4830. [CrossRef]

39. Chronwall, B.M. Anatomical distribution of NPY and NPY messenger RNA in rat brain. In Neuropeptide Y; Mutt, V., Ed.; Raven Press: New York, NY, USA, 1989; pp. 51-59.

40. Danger, J.M.; Tonon, M.C.; Basille, C.; Jenks, B.G.; Saint Pierre, S.; Martel, J.C.; Fasolo, A.; Quirion, R.; Pelletier, G.; Vaudry, H. Neuropeptide Y: Localization in the central nervous system and neuroendocrine functions. Fundam. Clin. Pharmacol. 1990, 4, 307-340. [CrossRef]

41. Morris, B.J. Neuronal localisation of neuropeptide Y gene expression in rat brain. J. Comp. Neurol. 1989, 290, 358-368. [CrossRef] [PubMed]

42. Gumbs, M.C.R.; Vuuregge, A.H.; Eggels, L.; Unmehopa, U.A.; Lamuadni, K.; Mul, J.D.; la Fleur, S.E. Afferent neuropeptide Y projections to the ventral tegmental area in normal-weight male Wistar rats. J. Comp. Neurol. 2019, 527, 2659-2674. [CrossRef] [PubMed]

43. Watson, S.J.; Richard, C.W., 3rd; Barchas, J.D. Adrenocorticotropin in rat brain: Immunocytochemical localization in cells and axons. Science 1978, 200, 1180-1182. [CrossRef]

44. Jacobowitz, D.M.; O'Donohue, T.L. alpha-Melanocyte stimulating hormone: Immunohistochemical identification and mapping in neurons of rat brain. Proc. Natl. Acad. Sci. USA 1978, 75, 6300-6304. [CrossRef]

45. Bagnol, D.; Lu, X.Y.; Kaelin, C.B.; Day, H.E.; Ollmann, M.; Gantz, I.; Akil, H.; Barsh, G.S.; Watson, S.J. Anatomy of an endogenous antagonist: Relationship between Agouti-related protein and proopiomelanocortin in brain. J. Neurosci. 1999, 19, RC26. [CrossRef]

46. King, C.M.; Hentges, S.T. Relative number and distribution of murine hypothalamic proopiomelanocortin neurons innervating distinct target sites. PLoS ONE 2011, 6, e25864. [CrossRef]

47. Heindel, J.J.; Vom Saal, F.S.; Blumberg, B.; Bovolin, P.; Calamandrei, G.; Ceresini, G.; Cohn, B.A.; Fabbri, E.; Gioiosa, L.; Kassotis, C.; et al. Parma consensus statement on metabolic disruptors. Environ. Health Glob. Access Sci. Source 2015, 14, 54. [CrossRef] [PubMed]

48. Cederroth, C.; Vinciguerra, M.; Kühne, F.; Madani, R.; Doerge, D.; Visser, T.; Foti, M.; Rohner-Jeanrenaud, F.; Vassalli, J.-D.; Nef, S. A phytoestrogen-rich diet increases energy expenditure and decreases adiposity in mice. Environ. Health Perspect. 2007, 115, 1467-1473. [CrossRef] [PubMed]

49. Murata, Y.; Robertson, K.M.; Jones, M.E.; Simpson, E.R. Effect of estrogen deficiency in the male: The ArKO mouse model. Mol. Cell Endocrinol. 2002, 193, 7-12. [CrossRef]

50. Heine, P.A.; Taylor, J.A.; Iwamoto, G.A.; Lubahn, D.B.; Cooke, P.S. Increased adipose tissue in male and female estrogen receptor-alpha knockout mice. Proc. Natl. Acad. Sci. USA 2000, 97, 12729-12734. [CrossRef]

51. Welshons, W.V.; Nagel, S.C.; vom Saal, F.S. Large effects from small exposures. III. Endocrine mechanisms mediating effects of bisphenol A at levels of human exposure. Endocrinology 2006, 147, S56-S69. [CrossRef]

52. Allera, A.; Lo, S.; King, I.; Steglich, F.; Klingmuller, D. Impact of androgenic/antiandrogenic compounds (AAC) on human sex steroid metabolizing key enzymes. Toxicology 2004, 205, 75-85. [CrossRef]

53. De Souza, F.S.; Nasif, S.; Lopez-Leal, R.; Levi, D.H.; Low, M.J.; Rubinsten, M. The estrogen receptor alpha colocalizes with proopiomelanocortin in hypothalamic neurons and binds to a conserved motif present in the neuron-specific enhancer nPE2. Eur. J. Pharmacol. 2011, 660, 181-187. [CrossRef] [PubMed]

54. Marraudino, M.; Miceli, D.; Farinetti, A.; Ponti, G.; Panzica, G.; Gotti, S. Kisspeptin innervation of the hypothalamic paraventricular nucleus: Sexual dimorphism and effect of estrous cycle in female mice. J. Anat. 2017, 230, 775-786. [CrossRef] [PubMed]

55. Vandenberg, L.N.; Colborn, T.; Hayes, T.B.; Heindel, J.J.; Jacobs, D.R., Jr.; Lee, D.H.; Shioda, T.; Soto, A.M.; vom Saal, F.S.; Welshons, W.V.; et al. Hormones and endocrine-disrupting chemicals: Low-dose effects and nonmonotonic dose responses. Endocr. Rev. 2012, 33, 378-455. [CrossRef] [PubMed]

56. Arletti, R.; Benelli, A.; Bertolini, A. Oxytocin inhibits food and fluid intake in rats. Physiol. Behav. 1990, 48, 825-830. [CrossRef] 
57. Maejima, Y.; Sakuma, K.; Santoso, P.; Gantulga, D.; Katsurada, K.; Ueta, Y.; Hiraoka, Y.; Nishimori, K.; Tanaka, S.; Shimomura, K.; et al. Oxytocinergic circuit from paraventricular and supraoptic nuclei to arcuate POMC neurons in hypothalamus. FEBS Lett. 2014, 588, 4404-4412. [CrossRef]

58. Hrabovszky, E.; Kallo, I.; Steinhauser, A.; Merchenthaler, I.; Coen, C.W.; Petersen, S.L.; Liposits, Z. Estrogen receptor-beta in oxytocin and vasopressin neurons of the rat and human hypothalamus: Immunocytochemical and in situ hybridization studies. J. Comp. Neurol. 2004, 473, 315-333. [CrossRef]

59. Forsling, M.L.; Kallo, I.; Hartley, D.E.; Heinze, L.; Ladek, R.; Coen, C.W.; File, S.E. Oestrogen receptor-beta and neurohypophysial hormones: Functional interaction and neuroanatomical localisation. Pharmacol. Biochem. Behav. 2003, 76, 535-542. [CrossRef]

60. Gamber, K.M.; Macarthur, H.; Westfall, T.C. Cannabinoids augment the release of neuropeptide Y in the rat hypothalamus. Neuropharmacology 2005, 49, 646-652. [CrossRef]

61. Koch, M.; Varela, L.; Kim, J.G.; Kim, J.D.; Hernandez-Nuno, F.; Simonds, S.E.; Castorena, C.M.; Vianna, C.R.; Elmquist, J.K.; Morozov, Y.M.; et al. Hypothalamic POMC neurons promote cannabinoid-induced feeding. Nature 2015, 519, 45-50. [CrossRef] [PubMed]

62. Gonzalez, S.; Mauriello-Romanazzi, G.; Berrendero, F.; Ramos, J.A.; Franzoni, M.F.; Fernandez-Ruiz, J. Decreased cannabinoid CB1 receptor mRNA levels and immunoreactivity in pituitary hyperplasia induced by prolonged exposure to estrogens. Pituitary 2000, 3, 221-226. [CrossRef]

63. Suglia, A.; Chianese, R.; Migliaccio, M.; Ambrosino, C.; Fasano, S.; Pierantoni, R.; Cobellis, G.; Chioccarelli, T. Bisphenol A induces hypothalamic down-regulation of the the cannabinoid receptor 1 and anorexigenic effects in male mice. Pharmacol. Res. 2016, 113, 376-383. [CrossRef]

64. Garcia, S.M.; Hirschberg, P.R.; Sarkar, P.; Siegel, D.M.; Teegala, S.B.; Vail, G.M.; Routh, V.H. Insulin actions on hypothalamic glucose-sensing neurones. J. Neuroendocrinol. 2021, 33, e12937. [CrossRef]

65. Farrugia, F.; Aquilina, A.; Vassallo, J.; Pace, N.P. Bisphenol A and Type 2 Diabetes Mellitus: A Review of Epidemiologic, Functional, and Early Life Factors. Int. J. Environ. Res. Public. Health 2021, 18, 716. [CrossRef] [PubMed]

66. Hao, C.J.; Cheng, X.J.; Xia, H.F.; Ma, X. The endocrine disruptor diethylstilbestrol induces adipocyte differentiation and promotes obesity in mice. Toxicol. Appl. Pharmacol. 2012, 263, 102-110. [CrossRef] [PubMed]

67. Ahmed, E.I.; Zehr, J.L.; Schulz, K.M.; Lorenz, B.H.; DonCarlos, L.L.; Sisk, C.L. Pubertal hormones modulate the addition of new cells to sexually dimorphic brain regions. Nat. Neurosci. 2008, 11, 995-997. [CrossRef] [PubMed]

68. Morishita, M.; Maejima, S.; Tsukahara, S. Gonadal Hormone-Dependent Sexual Differentiation of a Female-Biased Sexually Dimorphic Cell Group in the Principal Nucleus of the Bed Nucleus of the Stria Terminalis in Mice. Endocrinology 2017, 158, 3512-3525. [CrossRef] [PubMed]

69. Bouret, S.G. Development of Hypothalamic Circuits That Control Food Intake and Energy Balance. In Appetite and Food Intake: Central Control; Harris, R.B.S., Ed.; CRC Press: Boca Raton, FL, USA, 2017; pp. 135-154.

70. Ishii, Y.; Bouret, S.G. Embryonic birthdate of hypothalamic leptin-activated neurons in mice. Endocrinology 2012, 153, 3657-3667. [CrossRef] [PubMed]

71. Melnick, I.; Pronchuk, N.; Cowley, M.A.; Grove, K.L.; Colmers, W.F. Developmental switch in neuropeptide Y and melanocortin effects in the paraventricular nucleus of the hypothalamus. Neuron 2007, 56, 1103-1115. [CrossRef]

72. Safahani, M.; Aligholi, H.; Noorbakhsh, F.; Djalali, M.; Pishva, H.; Modarres Mousavi, S.M.; Alizadeh, L.; Gorji, A.; Koohdani, F. Switching from high-fat diet to foods containing resveratrol as a calorie restriction mimetic changes the architecture of arcuate nucleus to produce more newborn anorexigenic neurons. Eur. J. Nutr. 2019, 58, 1687-1701. [CrossRef]

73. Yirun, A.; Ozkemahli, G.; Balci, A.; Erkekoglu, P.; Zeybek, N.D.; Yersal, N.; Kocer-Gumusel, B. Neuroendocrine disruption by bisphenol A and/or di(2-ethylhexyl) phthalate after prenatal, early postnatal and lactational exposure. Environ. Sci. Pollut. Res. Int. 2021. [CrossRef] [PubMed]

74. Penza, M.; Jeremic, M.; Marrazzo, E.; Maggi, A.; Ciana, P.; Rando, G.; Grigolato, P.G.; Di Lorenzo, D. The environmental chemical tributyltin chloride (TBT) shows both estrogenic and adipogenic activities in mice which might depend on the exposure dose. Toxicol. Appl. Pharmacol. 2011, 255, 65-75. [CrossRef]

75. Harkness, J.E.; Wagner, J.E. The Biology and Medicine of Rabbits and Rodents, 3rd ed.; Lea and Febiger: Philadelphia, PA, USA, 1989.

76. Watson, R.E.; Wiegand, S.J.; Clough, R.W.; Hoffman, G.E. Use of cryoprotectant to maintain long-term peptide immunoreactivity and tissue morphology. Peptides 1986, 7, 155-159. [CrossRef]

77. Gouaze, A.; Brenachot, X.; Rigault, C.; Krezymon, A.; Rauch, C.; Nedelec, E.; Lemoine, A.; Gascuel, J.; Bauer, S.; Penicaud, L.; et al. Cerebral cell renewal in adult mice controls the onset of obesity. PLoS ONE 2013, 8, e72029. [CrossRef] [PubMed]

78. Kabra, D.G.; Pfuhlmann, K.; Garcia-Caceres, C.; Schriever, S.C.; Casquero Garcia, V.; Kebede, A.F.; Fuente-Martin, E.; Trivedi, C.; Heppner, K.; Uhlenhaut, N.H.; et al. Hypothalamic leptin action is mediated by histone deacetylase 5. Nat. Commun. 2016, 7, 10782. [CrossRef]

79. Pelletier, G.; Desy, L.; Kerkerian, L.; Cote, J. Immunocytochemical localization of neuropeptide Y (NPY) in the human hypothalamus. Cell Tissue Res. 1984, 238, 203-205. [CrossRef]

80. Pelletier, G.; Guy, J.; Allen, Y.S.; Polak, J.M. Electron microscopic immunocytochemical localization of neuropeptide Y (NPY) in the rat brain. Neuropeptides 1984, 4, 319-324. [CrossRef] 
81. Lemus, M.B.; Bayliss, J.A.; Lockie, S.H.; Santos, V.V.; Reichenbach, A.; Stark, R.; Andrews, Z.B. A stereological analysis of NPY, POMC, Orexin, GFAP astrocyte, and Iba1 microglia cell number and volume in diet-induced obese male mice. Endocrinology 2015, 156, 1701-1713. [CrossRef]

82. Marraudino, M.; Martini, M.; Trova, S.; Farinetti, A.; Ponti, G.; Gotti, S.; Panzica, G. Kisspeptin system in ovariectomized mice: Estradiol and progesterone regulation. Brain Res. 2018, 1688, 8-14. [CrossRef] [PubMed]

83. Paxinos, G.; Franklin, K.B.J. The Mouse Brain in Stereotaxic Coordinates, 2nd ed.; Academic Press: San Diego, CA, USA, 2001. 